\title{
Sulfated Polysaccharides in Diets for Nile tilapia (Oreochromis niloticus) in the Initial Growth Phase
}

Bruno Chaves Fabrini, Weslley Fernandes Braga, Estefânia Souza Andrade, Daniela Aparecida de Jesus Paula, Renan Rosa Paulino, Adriano Carvalho Costa, Luciano Vilela Paiva, Fabrício Lelis da Silva and Luis David Solis Murgas*

Fish Physiology Research Center, Federal University of Lavras, Lavras-MG, Brazil

\begin{abstract}
This study had the objective of evaluating the performance of Nile tilapia, in initial growth phase, with the supplementation of fucoidan, extracted from brown algae, at 30 days of rearing. The experiment was conducted for a period of 30 days. We used 216 Nile tilapia fingerlings distributed in to twelve 60 liter tanks, in a completely randomized design, totalizing four treatments and tree replicates. The fingerlings were supplemented with powdered sulfated polysaccharide extract at the levels of $0 \%, 0.5 \%, 1.0 \%$ and $1.5 \%$. During the experimental period, two samplings were performed (initial and final) to measure zootechnical performance, muscle histology and blood plasma chromatography. The data were submitted to analysis of variance at a level of significance of $5 \%$. The performance variables muscle fiber diameter frequency and fucose plasmatic concentration were not significant among the treatments $(P>0.05)$. It was possible to identify fucose in the blood plasma of the animals, proving its efficiency in breaking the $\alpha-(1-3)$ bonds of the polysaccharide, thus absorbing this component. The histological analysis showed that there was a higher percentage of hypertrophic growth of the muscle fibers, given that, in all treatments, the diameter class $>50 \mu \mathrm{m}$ prevailed $(P<0.05)$. In conclusion, the sulfated polysaccharide fucoidan, used in diets for Oreochromis niloticus with 30 days of rearing, was not effective in increasing performance parameters and muscle growth.
\end{abstract}

Keywords: Fish farming; Oreochromis niloticus; Performance; Fucoidan

\section{Introduction}

According to the Food and Agriculture Organization, FAO [1], the consumption of fish has rapidly increased in recent years, especially in the last decades, going from $9.9 \mathrm{~kg}$ per individual in 1960s to 19.7 $\mathrm{kg}$ per individual in 2013. This increase in consumption leads to the demand, by the consumer, that management methods, breeding and nutrition be improved, thus increasing productivity.

In the fish production chain, the improvement of a few productive traits, such as specific growth, is essential for the success of the activity, given that, from the economic point-of-view, this trait is prominent for being intrinsically connected to productivity and production profitability. In this context, the use of economically feasible and natural nutritional compounds, capable of promoting such increment in animal growth, can be an important ally to the producer.

Muscle growth is positively and negatively controlled by a series of transcriptional and growth factors, which, in turn, control the proliferation and differentiation of the satellite cells. One of these factors is a protein of the transforming growth factor-B (TGF-B) family, known as myostatin or Growth/Differentiation Factor-8 (GDF-8), and has the main function of negatively regulating muscle growth, controlling the formation of new muscle fibers and inhibiting the hypertrophy of the existing fibers $[2,3]$. The knowledge and effect of this protein in the workings of the organism has led to the increase in researches, especially in the genetic level, to inhibit its action, thus, promoting greater muscle growth.

Recently, the use of a sulfated polysaccharide, extracted from brown algae, known as Fucoidan, has demonstrated positive results in this sense. Ramazanov et al. [4], after conducting an immuno-electrophoresis analysis, in Western Blot, using proteins extracted from human blood serum incubated with sulfated polysaccharide, showed a positive cross reactivity with the antibody of the myostatin. This reactivity increased with the increase in the concentration of polysaccharides in the sample, indicating that the sulfated polysaccharides bonded, preferentially, to the myostatin complex and, potentially, interfere with the bonding capacity of this protein in the cells, inhibiting its action. Tuller et al. [5], with the objective of obtaining the same result, tested the increment of this polysaccharide at increasing levels in the feed of barramundi (Lates calcarifer). With the increase in the levels of Fucoidan, there was increase in animal growth and size of the muscle fiber. Similar results were also found by Cruz-Suárez [6] and Traifalgar [7], who worked with shrimp species.

Despite the results obtained in the in vivo researches, no molecular analysis was conducted to analyze, first, if the animals were effective in breaking the polysaccharide, thus absorbing its components, since it is formed by $\alpha-(1-3)$ bonds; and, posteriorly, its interaction with the action of myostatin. In this sense, this study had the objective of evaluating the performance of Nile tilapia, in initial growth phase, with the supplementation of different levels of sulfated polysaccharide (Fucoidan), extracted from brown algae, at 30 days of rearing, as well as their efficiency in breaking and absorbing this dietary component.

\section{Materials and Methods}

\section{Biological material and experimental conditions}

We used 216 reverted Nile tilapia (Oreochromis niloticus) fingerlings, with average initial weight of $2.73 \pm 0.19 \mathrm{~g}$. The fingerlings

*Corresponding author: Luis David Solis Murgas, Fish Physiology Research Director, Professor at Federal University of Lavras, Lavras-MG, Brazil, Tel: +55 35 3829-1122; E-mail: Ismurgas@dmv.ufla.br

Received December 14, 2016; Accepted May 02, 2017; Published May 04, 2017

Citation: Fabrini BC, Braga WF, Andrade ES, Paula DAD, Paulino RR, et al (2017) Sulfated Polysaccharides in Diets for Nile tilapia (Oreochromis niloticus) in the Initial Growth Phase. J Aquac Res Development 8: 477. doi: 10.4172/21559546.1000477

Copyright: (c) 2017 Fabrini BC, et al. This is an open-access article distributed under the terms of the Creative Commons Attribution License, which permits unrestricted use, distribution, and reproduction in any medium, provided the original author and source are credited. 
were maintained for observation, for two weeks, in two water recirculation tanks with capacity for 500 liters, at $26^{\circ} \mathrm{C}$. During this period, the animals were fed ad libitum with commercial feed $(45 \%$ $\mathrm{CP})$, specific to this species and life phase, three times a day (08 h: 00 min, 12 h: $00 \mathrm{~min}$ and $17 \mathrm{~h}: 00 \mathrm{~min})$.

After this period, the fish were randomly distributed in to the 12 experimental tanks, with capacity for 60 liters each. The groups were comprised of 18 animals, which were maintained in experimental conditions, with commercial ration, for a period of a week for adaptation, thus beginning the experiment with the initial sampling.

For a period of 30 days, the animals were daily fed ad libitum at the times of $08 \mathrm{~h}: 00 \mathrm{~min}, 12 \mathrm{~h}: 00 \mathrm{~min}$ and $17 \mathrm{~h}: 00 \mathrm{~min}$, using two experimental diets. The light period adopted was of 12 hours of light and 12 hours of dark. The water quality parameters, such as temperature, $\mathrm{pH}$ and dissolved oxygen, were monitored and maintained at $26.5^{\circ} \mathrm{C}$, $7.5 \mathrm{e}, 9.0 \mathrm{mg} \mathrm{L}^{-1}$, respectively, remaining within the normal values for the species [8]. The tanks were maintained in water recirculation system, filtered with biological and physical filters. All tanks were maintained with constant water flow. During the morning (09 h: 00 $\mathrm{min})$ an afternoon (16 h: $00 \mathrm{~min}$ ) of every day, the tanks were cleaned of feces and, twice per week, the filters were cleaned.

Both experimental samplings (initial and final) were obtained after anesthesia, with clove oil at $80 \mathrm{mg} / \mathrm{L}$ [9], and posterior slaughter of nine animals per tank at each sampling. The slaughtered animals were used for obtaining the data for zootechnical indexes, fucose level in the blood plasma and muscle extraction for histological analysis.

All experimental procedures were carried out in accordance with the Ethics Commission on Animal Use (CEUA) of the Federal University of Lavras (UFLA)

\section{Zootechnical indexes}

The animals were weighed on precision scale, and the morphometric measures were assessed with the aid of ruler graduated in millimeters $(\mathrm{mm})$. The measures taken were: Total Length (TL), consisted of the beginning of the mouth to the end of the caudal fin; Head Length (HL), consisted of the rear end of the head to the caudal edge of the operculum; Standard Length (SL), consisted of the rear extremity of the head to the smallest perimeter of the peduncle (insertion of the caudal fin); Body Height $(\mathrm{BH})$, body height measured in front of the $1^{\text {st }}$ radius of the dorsal fin.

By means of the weight, morphometric measures and mortality, we evaluated:

Survival rate $(S \%)=($ final number of fishes / initial number of fishes $) \times 100$

Final average weight gain $(W G)=$ final weight - initial weight

Average ration consumption $(R C)=$ final quantity of ration-initial

quantity of ration

\section{Evaluation of the skeletal muscle fibers}

For the histological analysis, fragments of white muscle were extracted from the left dorsal region of the fishes. These fragments were involved by neutral powder and, subsequently, the samples were frozen in liquid nitrogen and, posteriorly, stored in freezer at $-80^{\circ} \mathrm{C}$.

For the confection of the laminas, transversal sections of $10 \mu \mathrm{m}$ of thickness were obtained in cryostat at $-20^{\circ} \mathrm{C}$ (Leica, Germany) and the cuts were submitted to coloration with hematoxylin and eosin for morphological studies.
The histological laminas were photographed using an Olympus CX31 microscope (Olympus, Japan), coupled to an Altra SC30 digital camera (Olympus, Japan) and, using the AxioVision program (Carl Zeiss, Germany), the diameter of 200 muscle fibers was measured per lamina (animal) [10].

The data regarding the diameters of the muscle fibers were distributed in diameter classes $(<25 \mu \mathrm{m}, 25-50 \mu \mathrm{m}$ and $>50 \mu \mathrm{m})$, according to methodology adopted by Almeida et al. [11], and the means were plotted in frequency histogram (\%) for each treatment, at 30 days.

\section{Plasmatic levels of fucose}

After sampling blood and the posterior extraction of blood serum, the samples underwent readings of liquid chromatography coupled to mass chromatography, to identify and differentiate the levels of fucose.

The samples of plasma were prepared with the dilution in the proportion to 1:100 and filtering by PES membrane, with pore diameter of $0.22 \mu \mathrm{m}$. A volume of $10 \mu \mathrm{L}$ of these samples was injected in to a UFLC system (Shimadzu, Kyoto, Japan) comprised of two pumps (LC20AD) and a gas relief (DGU-20A $\mathrm{A}_{3}$ ), by an automatic injector (SIL-20A HT) equipped with a $100 \mu \mathrm{L}$ loop. The system was operated by software Hystar (BrukerDaltonik, v. 3.2.44.0).

A pre-column of $5 \mathrm{~mm}$ and an analytical column of $150 \mathrm{~mm} \times$ $75 \mu \mathrm{m}$, filled with stationary phase C18, $2.7 \mu \mathrm{m}$ (Supelco, Bellefonte, Pennsylvania, United States) were used for separating the metabolites, which were analyzed in a mass spectrometer (microTOF Q-II, BrukerDaltonik, Bremen, Germany), equipped with an electrospray ionization interface. The samples were carried by flow of $200 \mu \mathrm{L}$. min $^{-1}$ of acetonitrile solution at $20 \%(\mathrm{v} / \mathrm{v})$ and $0.1 \%(\mathrm{v} / \mathrm{v})$ AF in water (Fluka, Buchas, Switzerland).

The mobile phase used for separation was prepared with gradient between water containing $0.1 \%(\mathrm{v} / \mathrm{v})$ AF LC-MS Chromaslov (Fluka) - solution A, and acetonitrile containing $0.1 \%$ (v/v) AF LC-MS Chromaslov (Fluka) - solution B. The program used for elution was configured with the following proportions: $0-2$ min isocratic $2 \% \mathrm{~B} ; 2-12$ min linear gradient up to $10 \% \mathrm{~B} ; 12-17$ linear gradient up to $98 \% \mathrm{~B} ; 17$ $23 \mathrm{~min}$ isocratic $98 \% \mathrm{~B} ; 23 / 25 \mathrm{~min}$ isocratic $2 \% \mathrm{~B}$. The configurations used in the mass spectrometry were: mass interval: $50-1000 \mathrm{~m} / \mathrm{z}$; spray voltage: $3500 \mathrm{~V}$; drying gas $\left(\mathrm{N}_{2}\right)$ temperature: $190^{\circ} \mathrm{C}$; flow: $9 \mathrm{~L} \cdot \mathrm{min}^{-1}$; funnel 1 RF 200.0 Vpp; funnel 2 RF 200.0 Vpp; Hexapole RF 96.0 Vpp; quadrupole energy $-3.0 \mathrm{eV}$; smaller mass of the quadrupole $100.00 \mathrm{~m} / \mathrm{z}$; collision energy $-8.0 \mathrm{eV}$; collision RF $150.0 \mathrm{Vpp}$; transfer time $70 \mathrm{us}$; storage pre-pulse 5.0 us.

The chromatographic data obtained via LC-MS were analyzed with software Bruker Data Analysis, version 4.0 (Build 253), generating the EIC for $\mathrm{m} / \mathrm{z}$ 163.05, correspondent to fucose. We also collected the values for area under the spike for comparison between samples. A high-performance liquid chromatography (HPLC) method has been used previously for the determination of fucose [12].

\section{Fucoidan extract}

The powdered fucoidan extract, derived from the brown algae species Undaria pinnatifida, with purity of $70 \%$, was extracted from capsules of a commercial product and, posteriorly, added to the mixture of ingredients during the confection of the experimental diets.

\section{Experimental diets}

The experimental diets (Table 1) were formulated and balanced 
Citation: Fabrini BC, Braga WF, Andrade ES, Paula DAD, Paulino RR, et al. (2017) Sulfated Polysaccharides in Diets for Nile tilapia (Oreochromis niloticus) in the Initial Growth Phase. J Aquac Res Development 8: 477. doi: 10.4172/2155-9546.1000477

Page 3 of 6

according to the demands of the species and for the fingerling phase. The fucoidan extract was added to the base diet at the levels of 0 (T1), 5 (T2), 10 (T3) and $15 \mathrm{~g} / \mathrm{kg}$ (T4). After homogenization of the product with the ration ingredients (dry), the diets received treatment with water at $60^{\circ} \mathrm{C}$. The rations, agglutinated, underwent pelletizing and, the formed pellets underwent a drying process in oven $\left(45^{\circ} \mathrm{C}\right)$ under forced ventilation, for a period of 24 hours.

\section{Statistical analyses}

With the fundamental hypothesis for analysis of variance met, the data for zootechnical performance and chromatography were submitted to analysis of variance with a level of significance of $5 \%$. The diameter frequencies were submitted to analysis by the Goodman test. All analyses were performed with the aid of the R computer program, version 3.0.1 [13]

\section{Results}

\section{Zootechnical indexes}

Regarding the performance variables, final weight (FW), average ration consumption (RC), final average weight gain (FWG), apparent food conversion (AFC), survival (S) and morphometric measures standard length (SL), head length (HL) and body height (BH), there was no significant difference between the treatments $(\mathrm{P}>0.05)$ (Tables 2 and 3 ).

\section{Plasma levels of fucose}

Chromatography was incapable of identifying the presence of monosaccharide fucose in the blood plasma of the animals during initial sampling. At the end of the experiment, its presence was identified in all treatments (Figure 1), however, there was no significant difference between the evaluated treatments $(\mathrm{P}>0.05)$. We verified the tendency of increase in the levels of fucose with the increase of the levels of fucoidan provided. The average values of the fucose spike areas, in arbitrary units, were of: $841.87 \pm 420.99$ (T1), $2533.60 \pm 189.32$ (T2), $4606.23 \pm$ 2202.63 (T3) and $2176.85 \pm 833.89(\mathrm{~T} 4)$.

\section{Evaluation of skeletal muscle fibers}

Table 4 demonstrated data regarding the distribution of the muscle fibers for the studied classes, at 30 days of rearing. There was no significant difference between treatments, since, in all treatments, the fiber frequency in the class $>50 \mu \mathrm{m}$ was the highest, followed by classes $20-50 \mu \mathrm{m}$ and $<20 \mu \mathrm{m}(\mathrm{P}<0.05)$. This result shows that there was a higher percentage of hypertrophic growth of the muscle fibers (Figure 2).

\section{Discussion}

The first evidences that the polysaccharides presented the effective capacity of inhibiting the action of myostatin, thus promoting an elevated hyperplasia and hypertrophy rate in the muscle cells, were demonstrated by Ramazanov et al. [4]. In their work, an immuneelectrophoresis analysis, in Western Blot, on proteins extracted from human blood serum and incubated with sulfated polysaccharide. The results showed a positive cross reactivity with the antibody of the myostatin. This reactivity increased with the increase of the concentration of polysaccharides in the sample, indicating that the sulfated polysaccharides bond, preferentially, to the myostatin complex and, potentially, interfere with the bonding capacity of this protein in the cells, inhibiting its action. From this study emerged the idea of testing this polysaccharide as part of a feeding program, in order to obtain the same results.

\begin{tabular}{|c|c|c|c|c|}
\hline \multirow{2}{*}{ Ingredients (\%) } & Diet 1 & Diet 2 & Diet 3 & Diet 4 \\
\hline & 0 & 0.5 & 1 & 1.5 \\
\hline SoyBran & 40 & 40 & 40 & 40 \\
\hline Fishmeal & 15 & 15 & 15 & 15 \\
\hline Cornmeal & 15 & 15 & 15 & 15 \\
\hline Wheat Bran & 12.93 & 12.93 & 12.93 & 12.93 \\
\hline Corn Gluten & 5 & 5 & 5 & 5 \\
\hline Gelatine & 1 & 1 & 1 & 1 \\
\hline Soybean Oil & 3.5 & 3.5 & 3.5 & 3.5 \\
\hline Bicalcium Phosphate & 1 & 1 & 1 & 1 \\
\hline Sodium Chloride & 0.1 & 0.1 & 0.1 & 0.1 \\
\hline $\begin{array}{l}\text { Fucoidan } \\
\text { Cellulose } \\
\text { Inerte }\end{array}$ & $\begin{array}{c}0 \\
2.15 \\
3.8 \\
\end{array}$ & $\begin{array}{l}0.71 \\
1.43 \\
2.54\end{array}$ & $\begin{array}{l}1.43 \\
0.72 \\
1.27\end{array}$ & $\begin{array}{c}2.14 \\
0 \\
0\end{array}$ \\
\hline Vit/Min Premix ${ }^{1}$ & 0.5 & 0.5 & 0.5 & 0.5 \\
\hline $\mathrm{BHT}^{2}$ & 0.02 & 0.02 & 0.02 & 0.02 \\
\hline Total & 100 & 100 & 100 & 100 \\
\hline Calculated Values (\%) & 0 & 0.5 & 1 & 1.5 \\
\hline $\begin{array}{c}\text { Crude Protein } \\
\text { Digestible Protein }\end{array}$ & $\begin{array}{l}35.77 \\
31.98\end{array}$ & $\begin{array}{l}35.77 \\
31.98\end{array}$ & $\begin{array}{l}35.77 \\
31.98\end{array}$ & $\begin{array}{l}35.77 \\
31.98\end{array}$ \\
\hline Total Lipid & 6.77 & 6.77 & 6.77 & 6.77 \\
\hline $\begin{array}{c}\text { Digestible Energy }(\mathrm{kcal} / \mathrm{kg}) \\
\text { Total Fiber }\end{array}$ & $\begin{array}{l}3288.65 \\
2.07\end{array}$ & $\begin{array}{c}3288.65 \\
2.07\end{array}$ & $\begin{array}{l}3288.65 \\
2.07\end{array}$ & $\begin{array}{c}3288.65 \\
2.07\end{array}$ \\
\hline
\end{tabular}

${ }^{1}$ Vitamin and mineral mix provided the following $\left(\mathrm{kg}^{-1}\right.$ of product): $\mathrm{Fe} 19621 \mathrm{mg}, \mathrm{Cu}$ $2800 \mathrm{mg}$, Zn $28000 \mathrm{mg}$, Mn $5200 \mathrm{mg}$, Se $119 \mathrm{mg}$, Co $40 \mathrm{mg}$, I $120 \mathrm{mg}$, vitamin A 1995 KUI, vitamin D3 798 KUI, vitamin E 19950 mg, vitamin K3 997 mg, thiamin $4987 \mathrm{mg}$, riboflavin $4987 \mathrm{mg}$, pyridoxin $4987 \mathrm{mg}$, cyanocobalamin $5985 \mathrm{mcg}$, niacin $19950 \mathrm{mg}$, pantothenic acid $9975 \mathrm{mg}$, folic acid $997 \mathrm{mg}$, biotin 159600 mcg, inositol $10000 \mathrm{mg}$, vitC $70000 \mathrm{mg}$, ethoxyquin $24775 \mathrm{mg}$.

${ }^{2}$ Antioxidant: butylated hydroxytoluene.

Table 1: Diet composition with the levels of fucoidan.

\begin{tabular}{|c|c|c|c|c|c|}
\hline $\begin{array}{c}\text { Levels of Fucoidan } \\
(\mathbf{g} / \mathbf{k g})\end{array}$ & $\mathbf{F W}^{1}$ & $\mathbf{R C}^{\mathbf{2}}$ & $\mathbf{W G}^{3}$ & $\mathbf{A F C}^{4}$ & $\mathbf{S}^{5}$ \\
\hline 0.0 & $14.25 \pm$ & $12.66 \pm$ & $11.36 \pm$ & $1.12 \pm$ & $86 \pm 0.09$ \\
\hline 0.5 & 0.72 & 0.76 & 0.75 & 0.06 & \\
\hline \multirow{2}{*}{1.0} & $12.56 \pm$ & $12.94 \pm$ & $10.01 \pm$ & $1.29 \pm$ & $93 \pm 0.06$ \\
\hline \multirow{2}{*}{1.5} & 0.10 & 0.68 & 0.22 & 0.09 & \\
\hline CV & $11.38 \pm$ & $12.90 \pm$ & $8.57 \pm$ & $1.58 \pm$ & $96 \pm 0.03$ \\
\hline & 1.25 & 0.46 & 1.24 & 0.27 & \\
\hline & $13.29 \pm$ & $12.72 \pm$ & $10.62 \pm$ & $1.25 \pm$ & $96 \pm 0.03$ \\
\hline & 1.63 & 0.32 & 1.60 & 0.19 & \\
\hline
\end{tabular}

${ }^{1} \mathrm{Fw}=$ Final Average Weight $(\mathrm{g}) ;{ }^{2} \mathrm{RC}=$ Average Ration Consumption/Anima (g); ${ }^{3} \mathrm{WG}=$ Final Average Weight Gain (g); ${ }^{4} \mathrm{AFC}=$ Aparente Food Conversion; ${ }^{5} \mathrm{~S}=$ Survival $(\%)$

Table 2: Average values of the performance variables of Oreochromis niloticus supplemented with powdered fucoidan extract during 30 rearing days.

\begin{tabular}{|c|c|c|c|}
\hline $\begin{array}{c}\text { Levels of } \\
\text { Fucoidan } \mathbf{( g / k g )}\end{array}$ & $\mathbf{C P}^{1}$ & $\mathbf{C C}^{\mathbf{2}}$ & $\mathbf{A T}^{\mathbf{3}}$ \\
\hline 0.0 & $7.22 \pm 0.11$ & $2.40 \pm 0.02$ & $2.88 \pm 0.07$ \\
\hline 0.5 & $6.84 \pm 0.04$ & $2.34 \pm 0.03$ & $2.63 \pm 0.03$ \\
\hline 1.0 & $6.68 \pm 0.28$ & $2.31 \pm 0.13$ & $2.53 \pm 0.09$ \\
\hline 1.5 & $7.01 \pm 0.34$ & $2.46 \pm 0.11$ & $2.68 \pm 0.13$ \\
\hline $\mathrm{CV}$ & 5.70 & 6.42 & 5.63 \\
\hline${ }^{1} \mathrm{SL}=$ Standard Length $(\mathrm{cm}) ;{ }^{2} \mathrm{HL}=$ Head Length $(\mathrm{cm}) ;{ }^{3} \mathrm{BH}=$ Body Height $(\mathrm{cm})$ \\
\hline
\end{tabular}

Table 3: Average values for the morphometric measures of Oreochromis niloticus supplemented with powdered fucoidan extract during 30 rearing days.

In this study, the sulfated polysaccharide, Fucoidan, was incapable of increasing performance rates and muscle growth, both hyperplastic and hypertrophic, between the treatments, since none of the variables presented significant differences $(P>0.05)$ with the increase in the levels of the product. Similar performance results, regarding the levels 
Citation: Fabrini BC, Braga WF, Andrade ES, Paula DAD, Paulino RR, et al. (2017) Sulfated Polysaccharides in Diets for Nile tilapia (Oreochromis niloticus) in the Initial Growth Phase. J Aquac Res Development 8: 477. doi: 10.4172/2155-9546.1000477

of sulfated polysaccharides, were found by Lima [14], who tested the effect of administering sulfated polysaccharides at the levels of $0.0,0.5$, 1.0 and $2.0 \mathrm{mg} \mathrm{L}^{-1}$, over survival and growth of juvenile shrimp, species Litopenaeus vannamei, submitted to conditions of stress by hypoxia.

In counterpart, Tuller et al. [5], who tested levels of inclusion of $0 \%, 0.5 \%$ and $1 \%$ in diets for barramundi (Lates calcarifer) $(76.1 \pm$ $1.1 \mathrm{~g}$ ) for 52 days, found significant results. With the increase in the level of Fucoidan, there was an increase in animal growth and size of the muscle fiber. Similar results were found by Cruz-Suárez [6] and Traifalgar [7], who worked with shrimp species, L. vannamei (white shrimp) and Marsupenaeus japonicas (kuruma), respectively.

Due to the scarcity of papers with this product, for performance purposes, especially with fish species, its demands and the behavior of this polysaccharide within the animal organism are unknown. Thus, the levels used may not have been enough to meet the demands of the Nile tilapia regarding the effect of the product, since, when compared

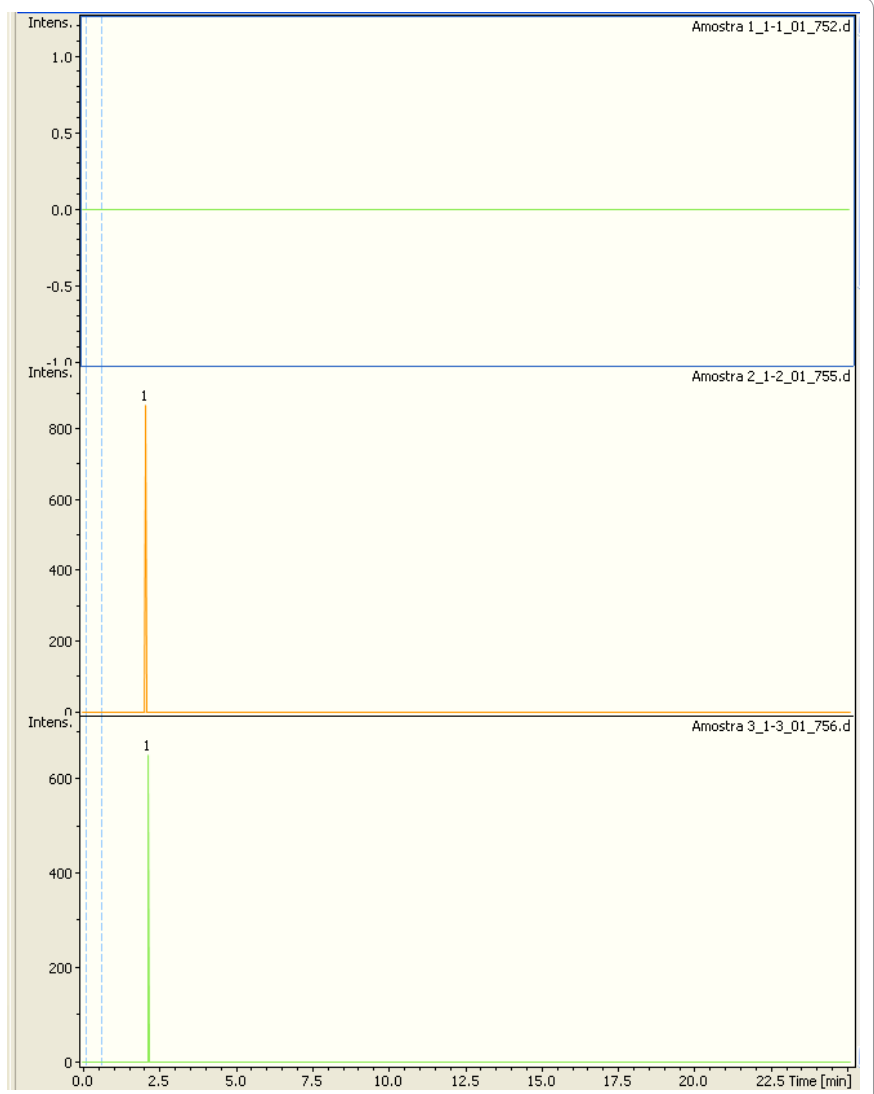

Figure 1: Ion chromatography, extracted for fucose $(\mathrm{m} / \mathrm{z}=163.05)$, of blood plasma of Oreochromis niloticus supplemented with powdered fucoidan extract during 30 rearing days. Example of tanks 1, 2 and 3 (Final sampling).

\begin{tabular}{|c|c|c|c|}
\hline Levels of Fucoidan $\mathbf{( g / k g )}$ & $<\mathbf{2 0}$ & $\mathbf{2 0}-\mathbf{5 0}$ & $>\mathbf{5 0}$ \\
\hline 0.0 & $5^{\mathrm{c}}$ & $36^{\mathrm{b}}$ & $59^{\mathrm{a}}$ \\
\hline 0.5 & $4^{\mathrm{c}}$ & $33^{\mathrm{b}}$ & $63^{\mathrm{a}}$ \\
\hline 1.0 & $6^{\mathrm{c}}$ & $34^{\mathrm{b}}$ & $60^{\mathrm{a}}$ \\
\hline 1.5 & $5^{\mathrm{c}}$ & $32^{\mathrm{b}}$ & $63^{\mathrm{a}}$ \\
\hline
\end{tabular}

*Means followed by the same letters do not differ statistically by the Goodman test at $5 \%$ of probability.

Table 4: Frequency distribution (\%) of the diameter of white muscle fiber in classes: $<20 \mu \mathrm{m}, 20-50 \mu \mathrm{m}$ and $>50 \mu \mathrm{m}$ of Oreochromis niloticus supplemented with powdered fucoidan extract during 30 rearing days.
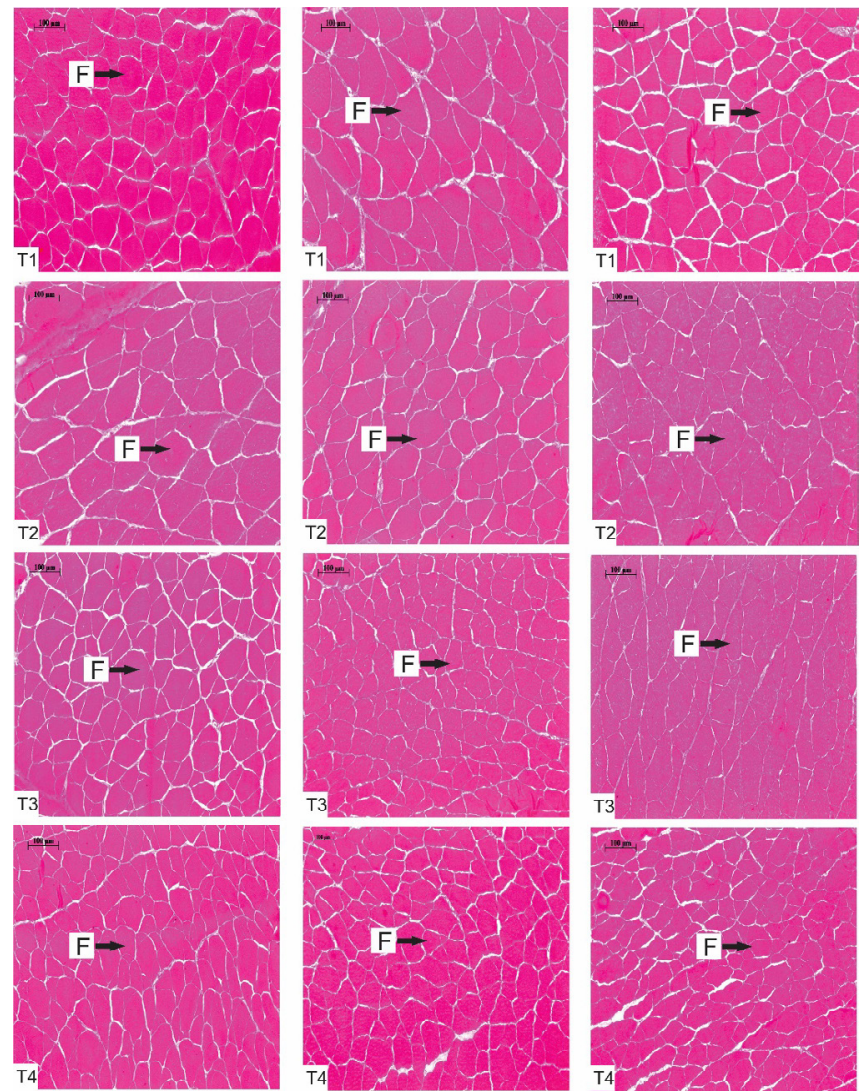

Figure 2: Transversal sections of the white muscle of Oreochromis niloticus cultivated in different levels of Fucoidan $(T 1=0, T 2=0.5, T 3=1.0$ e $T 4=1.5 \%)$, at 30 days. Muscle fiber (F). Haematoxylin and Eosina coloring. Magnification: 20x. Bar: $100 \mu \mathrm{m}$

to the barramundi [5], for example, in addition to refer to a different species, presents different feeding habits and distinguishes itself from the Nile tilapia regarding its region of origin. The barramundi is an animal of carnivorous habit, of cold water and Asian origin [15], while the Nile tilapia is an omnivorous species, of tropical climate and African origin [16].

In addition, we must consider the time spent in this study, which may not have been enough to obtain a response to the product, as well as the manner in which the product was incorporated to the experimental diets, given that, distinct from Ramazanov et al., [4], who used the intact polysaccharide molecule in direct contact with the blood cells, in this study, the animals would have no capacity of absorbing the molecule in this form in the gastrointestinal tract, due to the size of the molecule. This knowledge, added to the positive results obtained from the different authors, suggest that the effect of the polysaccharide can be caused not by the interaction of its integral structure with the cell, but by a specific monosaccharide present in the structure, such as fucose, which corresponds to more than $90 \%$ of its structure.

Since this concerns a polysaccharide with $\alpha-(1-3)$ bonds, another hypothesis for a possible positive performance was raised, since the animals may not have been capable of producing specific enzymes to break these bonds and thus absorb the fucose. In this sense, chromatography analysis were conducted, given that, for detecting the presence of fucose in the blood plasma, prove that the animals are capable of degrading the molecule and absorbing this component. 
Citation: Fabrini BC, Braga WF, Andrade ES, Paula DAD, Paulino RR, et al. (2017) Sulfated Polysaccharides in Diets for Nile tilapia (Oreochromis niloticus) in the Initial Growth Phase. J Aquac Res Development 8: 477. doi: 10.4172/2155-9546.1000477

In the study in question and that conducted by Traifalgar et al. [7], the knowledge of this compound in the animal organism has led to it being incorporated to the diets as fibrous element. However, with the exception of Lima et al. [14], who also found no significant differences between treatments, the authors made only the inclusion of the product, without considering the balance of the diets regarding the levels of fiber or even of energy, since it concerns a polysaccharide. In addition, in none of the works was conducted a molecular analysis with the objective of detecting any type of inhibition of the action of myostatin. Thus, the positive effect of the polysaccharide over growth, cannot be attributed only to this fact.

There are suppositions that can be made concerning the beneficial effect of the sulfated polysaccharides, or its constituents, over animal performance, discarding the hypothesis of its action over the myostatin molecule. A possible explanation is in the fact that fucose performes an important role in the maintenance of animal immune system and health of the intestinal flora.

Fucose, whether dietetic or of the organism, can be found as an important structural component of glucans. Specific terminal changes in glucans, including fucosylation, mediated by fucosyltransferases (FUT), can confer exclusive functional properties to a few oligosaccharides, and, are often regulated during ontogeny and cellular differentiation [17]

The discovery of thirteen genes capable of synthetizing fucosyltransferases in the human genome was describe [17]. The expression of these genes is responsible for many functions in the organism, such as synthesis of the $\mathrm{H}$ blood group antigen $[18,19]$; synthesis of Lewisx and sialyl-Lewisx antigens [20,21]; addition of fucose to GlcNAc asparagine [22]; and the addition of fucose directly in to polypeptide chains [23]. Thus, this functional property, within the composition of the oligosaccharides, confer to fucose an important role in the health of the immune system.

The expression of these fucosyltransferases can also be regulated by bacterial flora, as described by Hooper [24]. Microbiologically sterilized mice, when colonized by bacteria, were capable of increasing the expression of FUT2. Consequently, there were changes in the carbohydrate chain present in the epithelial cells, which presented fucose as terminal component.

In this sense, the health of the intestinal flora can be seen as an important component of maintaining the normal development of the animal, with the providing of fucose via diet aiding in this. It was proven that the bacteria are capable of growing while using fucose as a single source of carbon structure and energy [24]. The stages to this via include the entrance of free fucose to the cell by means of bacterial permease, fucose isomerization (aldose) to form fuculose (cetose), fuculose phosphorylation to form fuculose-1-phosphate, and an aldolase reaction to form lactadehyde and dihydroxyacetone phosphate [25-27]. It was proposed that fucose can also be synthetized from two units of tree carbons by a via operating in the inverse direction of its catabolic via $[28,29]$, however, this synthesis would by unnecessary, if the fucose be provided by the diet, conserving the energetic expense with its biosynthesis.

Considering that this monosaccharide was absorbed, as shows the chromatographic data, in addition to its use as fundamental structure of specific glucans, as aforementioned, we can suppose that it can be used as energy source for the animal, as occurs with glucose. In a study involving the intravenous administration of fucose (1-14C) to human patients, it was reported that $39 \%$ of the radioactivity injected was excreted in the form of $14 \mathrm{CO}_{2}$ [30], suggesting that fucose could be metabolized to smaller metabolic units. In an in vitro work, a catabolic via was identified in swine hepatocyte extracts, which can convert 1 mol of fucose to 2 mols of L-lactate [31].

Despite these suppositions, there are not enough scientific knowledge to extrapolate to other species, and it is yet unclear its contributions to in vivo metabolism.

\section{Conclusion}

In conclusion, the Fucoidan sulfated polysaccharide, used for diets for Oreochromis niloticus with 30 days of rearing, was ineffective in increasing the performance parameters and muscle growth. The animals were efficient in breaking the $\alpha-(1-3)$ bonds of the polysaccharide, and thus absorb the main structural component of the molecule, the monosaccharide fucose. The study was capable of directing future researches for the use of fucoidan a functional food, not discarding, however, the hypothesis of its inhibitory action to the molecule of myostatin.

\section{Acknowledgments}

The authors would like to thank Rede Mineira de Bioterismo-FAPEMIG, CNPq, FUNDECC, CEMIG and CAPES for financial support. The authors wish to thank FN Monographic for English translation and revision of this manuscript. The authors would like to thank Piscicultura Projeto Tambacu and Piscicultura Aquaporto for the donation of the biological material.

\section{References}

1. FAO (2016) The state of world fisheries and aquaculture. Contributing to food security and nutrition for all. Rome.

2. Langley B, Thomas M, Bishop A, Sharma M, Gilmour S, et al. (2002) Myostatin inhibits myoblast differentiation by down regulating MyoD expression. The Journal of Biological Chemistry 277: 49831-49840.

3. Lee CY, Hu SY, Gong HY, Chen MH, Lu JK et al. (2009) Suppression of myostatin with vector-based RNA interference causes a double muscle effect in transgenic zebrafish. Biochemical and Biophysical Research Communications 387: 766-771.

4. Ramazanov Z, Del-Rio MJ, Ziegenfuss T (2003) Sulfated polysaccharides of brown seaweed Cystoseira canariensis bind to serum myostatin protein. Acta Physiologica and Pharmacologica, Bulgarica 27: 101-106.

5. Tuller J, De Santis C, Jerry DR (2014) Dietary influence of Fucoidan supplementation on growth of Lates calcarifer (Bloch). Aquaculture 45 : 749-754.

6. Cruz-Suárez LE, Ricque-Marie D, Tapia-Salazar M, Guajardo-Barbosa C (2000) Uso de harina de kelp (Macrocystis pyrifera) en alimentos para camarón.

7. Traifalgar RF, Kira H, Thanh TH, Raafat MF, Laining A, et al. (2010) Influence of dietary fucoidan supplementation on growth and immunological response of juvenile Marsupenaeus japonicas. Journal of the World Aquaculture Society 41: 235-244.

8. El-Sayed AFM (2006) Tilapia culture. Massachusetts: CABI.

9. Delbon MC (2006) Ação da Benzocaína e do Óleo de Cravo sobre parâmetros fisiológicos de tilápia, Oreochromis niloticus. 91 p. Dissertação (Mestrado em Aquicultura). Universidade Estadual Paulista, Jaboticabal.

10. Dubowitz V, Brooke MH (1973) Muscle biopsy: A modern approach. London: WB Saunders

11. Almeida FLA, Carvalho RB, Pinhal D, Padovani CR, Martins C, et al (2008) Differential expression of myogenic regulatory factor MyoD in pacu skeletal muscle (Piaractus mesopotamicus Holmberg 1887: Serrasalminae Characidae, Teleostei) during juvenile and adult growth phases. Micron 39 1306-1311.

12. Campo GM, Campo S, Ferlazzo AM, Vinci R, Calatroni A (2001) Improved highperformance liquid chromatographic method to estimate aminosugars and its application to glycosaminoglycan determination in plasma and serum. Journal of chromatography. B, Biomedical sciences and applications 765: 151-160. 
Citation: Fabrini BC, Braga WF, Andrade ES, Paula DAD, Paulino RR, et al. (2017) Sulfated Polysaccharides in Diets for Nile tilapia (Oreochromis niloticus) in the Initial Growth Phase. J Aquac Res Development 8: 477. doi: 10.4172/2155-9546.1000477

Page 6 of 6

13. Core Team $R$ (2014) A language and environment for statistical computing Vienna: R Foundation for Statistical Computing.

14. Lima PCW, Torres VM, Rodrigues JAG, Sousa JJ, Lobo WR (2009) Effect of sulfated polysaccharides from the marine brown alga Spatoglossum schroeder in Litopenaeus vannamei juveniles. Revista Ciência Agronômica 40: 79-85.

15. Catacutan, MR, Coloso RM (1995) Effect of dietary protein to energy ratios on growth, survival, and body composition of juvenile Asian seabass, Lates calcarifer. Aquaculture 131: 125-133.

16. Romana-Eguia MRR, Ikeda M, Basiao ZU, Taniguchi N (2004) Genetic diversity in farmed Asian, Nile, and red hybrid tilapia stocks evaluated from microsatellite and mitochondrial DNA. Aquaculture 236: 131-150.

17. Becker DJ, Lowe JB (2003) Fucose: Biosynthesis and biological function in mammals. Glycobiology, Oxford 13: 41-53.

18. Kelly RJ, Rouquier S, Giorgi D, Lennon GG, Lowe JB (1995) Sequence and expression of a candidate for the human Secretor blood group alpha $(1,2)$ fucosyltransferase gene (FUT2). Homozygosity for an enzyme-inactivating nonsense mutation commonly correlates with the non- secretor phenotype. The Journal of Biological Chemistry 270: 4640-4649.

19. Larsen RD, Ernst LK, Nair RP, Lowe JB (1990) Molecular cloning, sequence, and expression of a human GDP-L-fucose:beta- Dgalactoside 2-alpha-Lfucosyltransferase cDNA that can form the $\mathrm{H}$ blood group antigen. Proceedings of the National Academy of Sciences, Washington 87: 6674-6678.

20. Kaneko M, Kudo T, Iwasaki H, Ikehara Y, Nishihara S, et al. (1999) Alpha1,3fucosyltransferase IX (Fuc-TIX) is very highly conserved between human and mouse; molecular cloning, characterization and tissue distribution of human Fuc-TIX. FEBS Letters, Amsterdam 452: 237-242.

21. Natsuka S, Lowe JB (1994) Enzymes involved in mammalian oligosaccharide biosynthesis. Current Opinion in Structural Biology 4: 683-691.

22. Miyoshi E, Noda K, Yamaguchi Y, Inoue S, Ikeda Y, et al. (1999) The alpha1-6- fucosyltransferase gene and its biological significance. Biochimica et Biophysica Acta 1473: 9-20.

23. Wang Y, Shao L, Shi S, Harris RJ, Spellman MW, et al. (2001) Modification of epidermal growth factorlike repeats with O-fucose: Molecular cloning and expression of a novel GDP-fucose protein O-fucosyltransferase. The Journal of Biological Chemistry 276: 40338-40345.

24. Hooper LV (2014) Immune cells prompt gut epithelial cells to produce carbohydrate nutrients for resident bacteria. Science 345: 1248-1249.

25. Chen YM, Zhu Y, Lin EC (1987) The organization of the fuc regulon specifying L-fucose dissimilation in Escherichia coli K12 as determined by gene cloning. Molecular Genetics and Genomics 210: 331-337.

26. Hooper LV, Xu J, Falk PG, Midtvedt T, Gordon JI (1999) A molecular sensor that allows a gut commensal to control its nutrient foundation in a competitive ecosystem. Proceedings of the national academy of sciences of the United States of America, Washington 96: 9833-9838.

27. Zhu Y, Lin EC (1988) A mutant crp allele that differentially activates the operons of the fuc regulon in Escherichia coli. Journal of Bacteriology 170: 2352-2358.

28. Huang PC, Miller ON (1958a) Studies on the metabolism of lactaldehyde. IV. The metabolism of D- rhamnulose-1-phosphate and 6-deoxy-L-sorbose-1phosphate. The Journal of Biological Chemistry 230: 805-815.

29. Huang PC, Miller ON (1958b) The metabolism of lactaldehyde. V. Metabolism of L-fucose. The Journal of Biological Chemistry 231: 201-205.

30. Segal S, Topper YJ (1960) On the biosynthesis of L-fucose and Lfucose metabolism in man. Biochimica et Biophysica Acta 42: 147-151.

31. Chan JY, Nwokoro NA, Schachter HL (1979) Fucose metabolism in mammals The conversion of L-fucose to two moles of L-lactate, of L-galactose to L-lactate and glycerate, and of Darabinose to L-lactate and glycollate. The Journal of Biological Chemistry 254: 7060-7068. 